\title{
Jak2 Is Necessary for Neuroendocrine Control of Female Reproduction
}

\author{
Sheng Wu, ${ }^{1}$ Sara Divall, ${ }^{1}$ Gloria E. Hoffman, ${ }^{3}$ Wei Wei Le, ${ }^{3}$ Kay-Uwe Wagner, ${ }^{2}$ and Andrew Wolfe ${ }^{1}$ \\ ${ }^{1}$ Department of Pediatrics, Johns Hopkins University School of Medicine, Baltimore, Maryland 21287, ${ }^{2}$ Eppley Institute for Research in Cancer and Allied \\ Diseases and Department of Pathology and Microbiology, University of Nebraska Medical Center, Omaha, Nebraska 68198, and ${ }^{3}$ Department of Biology, \\ Morgan State University, Baltimore, Maryland 21251
}

Gonadotropin-releasing hormone $(\mathrm{GnRH})$ neurons represent the final common output of signals from the brain that regulates reproductive function. A wide range of environmental factors impact GnRH neuron activity including disease, stress, nutrition, and seasonal cues, as well as gonadal steroid hormones. The CNS response is thought to be mediated, at least in part, through intermediate signaling molecules that affect GnRH neuronal activity. In vitro, GnRH neuronal cell lines respond to a variety of ligands that activate the Jak (Janus-activated kinase)/STAT (signal transducers and activators of transcription) intracellular signaling pathway. To determine its biological function in reproduction, we used Cre (cAMP response element)/LoxP technology to generate GnRH neuron-specific Jak2 conditional knock-out (Jak2 $\mathrm{G}^{-I-}$ ) mice. GnRH mRNA levels were reduced in Jak2 $\mathrm{G}^{-I-}$ mice when compared with controls, while the number of GnRH neurons was equivalent, indicating a reduction in $\mathrm{GnRH}$ gene expression. Secretion of GnRH is also reduced as basal serum luteinizing hormone $(\mathrm{LH})$ levels were significantly lower in female Jak $2 \mathrm{G}^{-/-}$mice while the pituitary responded normally to exogenous GnRH. Preovulatory LH surge levels were blunted in Jak2 $\mathrm{G}^{-1-}$ mice, which was correlated with reduced GnRH neuronal activation as assessed by c-Fos. However, the activation of GnRH neurons following release from estrogen-negative feedback is retained. Female Jak $2 \mathrm{G}^{-1-}$ mice exhibited significantly delayed puberty and first estrus, abnormal estrous cyclicity, and impaired fertility. These results demonstrate an essential role for Jak2 signaling in $\mathrm{GnRH}$ neurons for normal reproductive development and fertility in female mice.

\section{Introduction}

Gonadotropin-releasing hormone $(\mathrm{GnRH})$ is the key regulator of reproduction and sexual behavior. GnRH travels via the portal vasculature to the anterior pituitary stimulating the synthesis and secretion of luteinizing hormone (LH) and follicle-stimulating hormone (FSH) from the gonadotroph. LH and FSH are released into the circulation and stimulate the maturation and development of the gonads and the synthesis and secretion of the gonadal steroid hormones. GnRH neurons integrate signals that regulate reproduction, for example, nutrition, stress, developmental cues, and seasonal and circadian information, which in turn regulate the expression and secretion of GnRH (Nagatani et al., 1996; Porkka-Heiskanen et al., 1997; Bucholtz et al., 2000; Smith and Grove, 2002; Pitteloud et al., 2007; Popa et al., 2008). The cytokine family of hormones, growth factors, and chemokines interact with the cytokine class of receptors and have been implicated in the central regulation of reproduction (Argetsinger et al., 1993;

Received June 1, 2010; revised Sept. 27, 2010; accepted 0ct. 25, 2010.

This work was supported by National Institutes of Health (NIH) Grant R01 HD44608 to A.W. This research was also supported by the Eunice Kennedy Shriver National Institute of Child Health \& Human Development/NIH through cooperative agreement (U54 HD 58820) as part of the Specialized Cooperative Centers Program in Reproduction and Infertility Research. We gratefully acknowledge the advice and critical analysis of Fred Wondisford and Sally Radovick. The technical assistance of Lan Su and Dan Diaczok is also greatly appreciated.

Correspondence should be addressed to Sheng Wu, Department of Pediatrics, Johns Hopkins University School of Medicine, Baltimore, MD 21287. E-mail: swu24@jhmi.edu.

DOI:10.1523/JNEUROSCI.2974-10.2011

Copyright $\odot 2011$ the authors $\quad 0270-6474 / 11 / 310184-09 \$ 15.00 / 0$
Bartke et al., 1999; Danilovich et al., 1999; Stanley et al., 2000; Watanobe and Yoneda, 2001; Shillingford et al., 2002; Bates et al., 2003; Gao et al., 2004; Dozio et al., 2005), although the precise mechanisms of action are still being explored. Janus-activated kinase 2 (Jak2), signal transducers and activators of transcription 3 (STAT3) and STAT5 are expressed in models of GnRH neurons, such as the GN11 and GT1-7 cells (Argetsinger et al., 1993; Magni et al., 2007), and activation of Jak2 has been suggested to mediate the effects of cytokines such as leukemia inhibitory factor (LIF) and ciliary neurotrophic factor (CNTF) through their receptors on GnRH neurons (Dozio et al., 2005; Magni et al., 2007).

The cytokine receptors lack intrinsic kinase activity and require interaction with members of the Jak family of intracellular signaling molecules. Jak2 belongs to the nonreceptor tyrosine kinase family (Ihle, 1995). It is the predominant Jak mediating the responses of single-chain cytokine receptors and plays an important role in signaling via the gp130 receptor family or the class II cytokine receptors (Kisseleva et al., 2002). Receptor activation causes Jak2 autophosphorylation, which phosphorylates its associated receptor. The phosphorylated receptor provides multiple docking sites that recruit STAT proteins, of which there are six family members (STAT1-6) (Pellegrini and DusanterFourt, 1997). STAT is phosphorylated by Jak2, resulting in dimerization and translocation to the nucleus where it acts as a transcription factor to regulate gene expression (Ihle, 1995; Parganas et al., 1998). A complete knockout of the Jak2 gene in vivo 

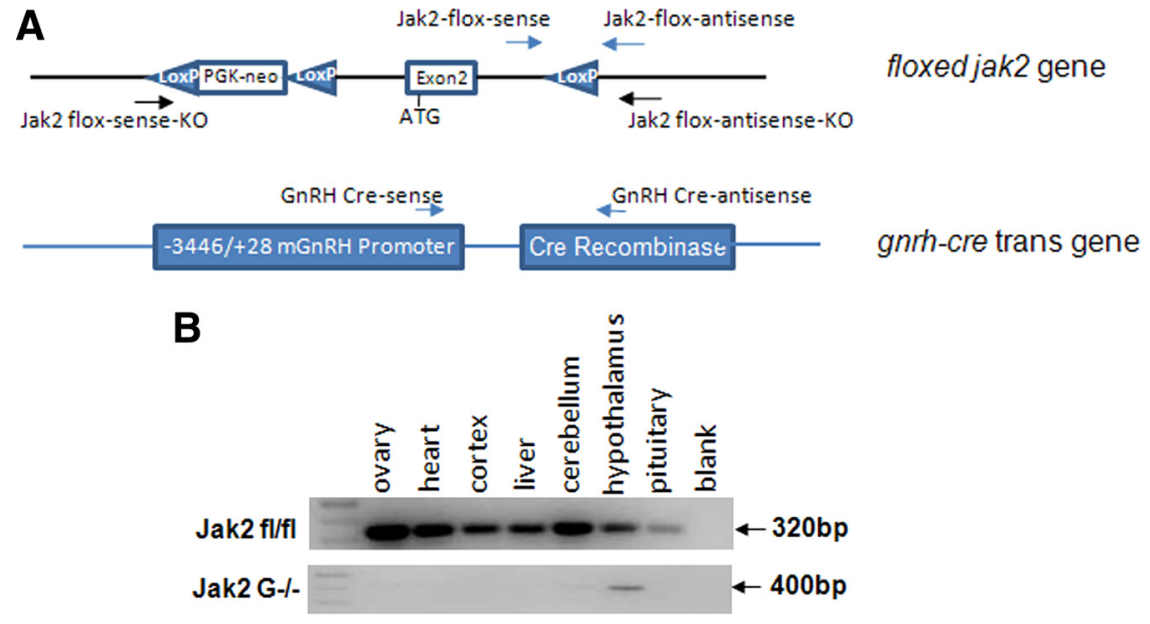

C

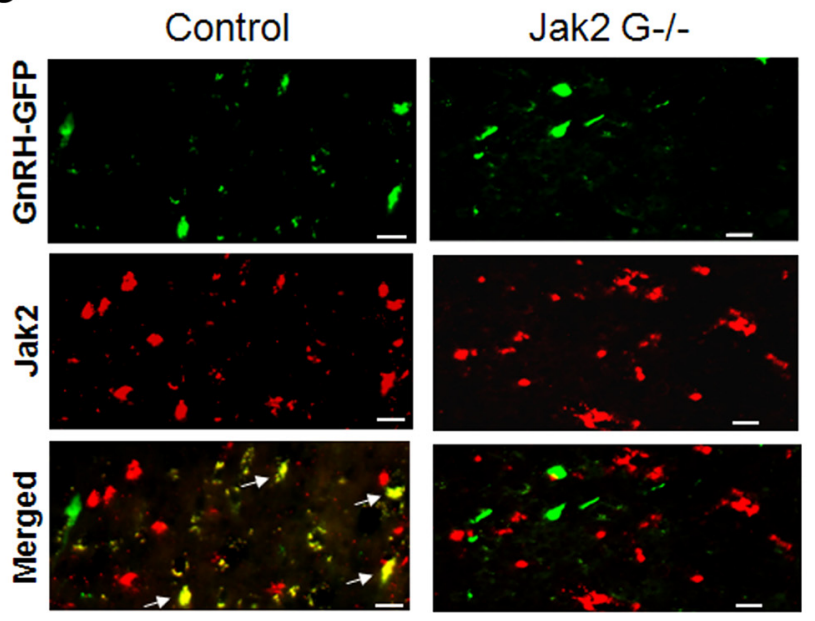

Figure 1. Generation of GnRH neuron-specific Jak2 knock-out mouse. $A$, Exon 2 of Jak2 is flanked by two LoxP sites, and Cre recombinase expression was regulated by the mouse GnRH promoter. Primers used in the PCRs are marked by arrows. $\boldsymbol{B}, \mathrm{PCR}$ of DNA isolated from various tissues of control and Jak2 $\mathrm{G}^{-1-}$ mice. C, Immunostaining of Jak2 in GnRH-GFP mice. Brain was sectioned at $10 \mu \mathrm{m}$ thick from control (left) and Jak2 $\mathrm{G}^{-1-}$ mice (right). GnRH neurons shown here are localized in the vertical limb of the diagonal band. Red is Jak2 immunostaining. Green is GnRH neuron. Yellow is colocalization (arrow) of Jak2 and GnRH. Scale bar, $20 \mu \mathrm{m}$.

has been produced and results in embryonic lethality (Parganas et al., 1998).

Since in vitro models provide evidence that Jak/STAT signaling may mediate important signals to the GnRH neurons, but in vivo evidence for a specific role for GnRH neuronal Jak2 is lacking, we therefore generated mice lacking Jak2 in GnRH neurons using the cAMP response element (Cre)/LoxP binary recombination system (Hamilton and Abremski, 1984; Singh et al., 2009) and report here a role for the Jak2 signaling molecule in the regulation of reproductive development and function in female mice.

\section{Materials and Methods}

Generation of GnRH neuron-specific Jak2 conditional knock-out mice. $\mathrm{GnRH}$ promoter-driven Cre recombinase (GnRH-Cre) transgenic mice were created in our laboratory on a CD1 background (Wolfe et al., 2008). $\mathrm{Jak} 2^{\mathrm{f} / \mathrm{fl}}$ mice were produced as previously described and were in a $129 \mathrm{SvJ}$ strain (Krempler et al., 2004). Exon 2 of Jak2 is flanked by loxP sites. Excision of exon 2 results in complete disruption of Jak2 expression (Krempler et al., 2004). The GnRH-Cre; Jak2 ${ }^{\mathrm{fl} / \mathrm{fl}}$ conditional knock-out (KO) mice, designated as Jak2 conditional knock-out $\left(J a k 2 \mathrm{G}^{-1-}\right)$ mice, were generated by first mating female $\left(\mathrm{GnRH}-\mathrm{Cre}^{+}\right)$with male $\left(\mathrm{Jak} 2^{\mathrm{fl} / \mathrm{fl}}\right)$ and then crossing a heterozygous (GnRH$\left.\mathrm{Cre}^{+} ; \mathrm{Jak} 2^{\mathrm{fl} / \mathrm{wt}}\right)$ female with a heterozygous $\left(\mathrm{GnRH}-\mathrm{Cre}^{-}\right.$; Jak2 $\left.{ }^{\mathrm{fl} / \mathrm{wt}}\right)$ male to generate six genotype combinations. GnRH-Cre ${ }^{+}$; Jak $2^{\text {fl/fl }}$ mice represent the homozygous conditional $\mathrm{KO}$ mice. GnRH-Cre ${ }^{-}$; Jak2 ${ }^{\text {fl/fl }}$ littermates were used as controls for all studies except for the mating and puberty assessments, which also used GnRH-Cre ${ }^{-}$; Jak2 ${ }^{\text {w/w }}$, $\mathrm{GnRH}_{-}-\mathrm{Cre}^{-}$; Jak2 ${ }^{\mathrm{fl} / \mathrm{wt}}$, and GnRH-Cre ${ }^{+}$; $\mathrm{Jak} 2{ }^{\mathrm{w} / \mathrm{w}}$ littermates due to limited litter sizes of our early matings. No difference was observed among these genotypes.

Animal housing. Mice were maintained with food and water ad libitum in a $14 / 10 \mathrm{~h}$ light/dark cycle at $24^{\circ} \mathrm{C}$ in the Broadway Research Building animal facility at the Johns Hopkins University School of Medicine. All procedures were approved by the Johns Hopkins University Animal Care and Use Committee.

tk;4Genotyping and DNA extraction. For genotyping, two pairs of primers were used: GnRH-Cre-specific primers: sense 5'-GGTAGCTTCAGCTGTGAAAG-3'; antisense 5'-CATCTTCAGGTTCTGCGGGAAACC- $3^{\prime}$; and Jak2 $2^{\mathrm{f} / \mathrm{fl}}$ primers: sense $5^{\prime}$-ATTCTGAGATTCAGGTCTGAGC-3'; antisense 5'-CTCACAACCATCTGTATCTCAC-3'.

To obtain genomic DNA of pups, a clipping from the ear or tail was collected from the mice and put into $10 \%$ chelex-100 resin (Bio-Rad) with $0.1 \%$ Tween-20 and $0.15 \mathrm{mg} / \mathrm{ml}$ proteinase K. Samples were incubated at $50^{\circ} \mathrm{C}$ for 90 min, proteinase $\mathrm{K}$ was inactivated at $95^{\circ} \mathrm{C}$ for $20 \mathrm{~min}$, and the solution was cooled to $10^{\circ} \mathrm{C}$. One microliter of supernatant was removed for PCR. The PCR was as follows: $94^{\circ} \mathrm{C}$ for $3 \mathrm{~min}$, 35 cycles with $94^{\circ} \mathrm{C}$ for $30 \mathrm{~s}, 58^{\circ} \mathrm{C}$ for $30 \mathrm{~s}, 72^{\circ} \mathrm{C}$ for $30 \mathrm{~s}$, and last cycle at $72^{\circ} \mathrm{C}$ for $7 \mathrm{~min}$. For identifying tissue-specific Jak2 allele recombination, different tissues were collected including hypothalamus, cerebellum, cortex, pituitary, liver, heart, ovary, and testes. DNA was obtained from these tissues by phenolchloroform extraction and isopropanol precipitation. Primers used for detection of Jak2 $\mathrm{G}^{-1-}$ : sense $5^{\prime}$-GTCTATACACCACCACTCCTG-3' and antisense 5'CGAGCTGGAAAGATAGGTCAGC- $3^{\prime}$. The sequences of the primers related to Jak2 are the same as in (Krempler et al., 2004). The locations of primers are labeled in Figure $1 A$.

Puberty and fertility examination. Female vaginal opening was assessed daily after $21 \mathrm{~d}$ of life. Following vaginal opening, daily vaginal cytology was performed in the morning by collecting vaginal cells using $0.9 \%$ saline lavage. Cells were dried on slides, fixed in ethanol, and stained with Diff-Quik staining kit (IMEB). Estrous cycle staging was assessed using the method previously described (Nelson et al., 1982). Proestrus was assigned as predominantly basal and cornified nucleated cells, estrus was assigned as predominantly cornified epithelial cells, metestrus was assigned as mixed cornified epithelial cells and leukocytes, and diestrus was assigned as predominantly leukocytes.

Adult female (2.5 months old) mice were mated with proven fertile adult male mice for a period of $90 \mathrm{~d}$. Time to each litter and litter size for each pair were recorded.

Total RNA extraction, reverse transcription, and real-time PCR. Hypothalamic RNA was extracted by Trizol (Invitrogen) according to the manufacturer's protocol. One microgram of total RNA was reverse transcribed (iScript cDNA Synthesis Kit, Bio-Rad) to cDNA. For GnRH, Taqman quantitative PCR (Bioresearch Technologies) was performed, 
and glyceraldehyde 3-phosphate dehydrogenase (GAPDH) was used as the internal control. Primers for GnRH: sense 5'-CCAACGGAAGCTCGAGATCC-3', and antisense 5'-TGCCGGCCATCAGTTTGAG-3' with the probe 5'TGACTTTCACATCCAAACAGAGTGGACA-3' labeled with FAM (5-carboxyfluorescein) and BHQ-1 (Black Hole Quencher-1).

Primers for GAPDH were as follows: sense 5'-GGGCATCTTGGGCTACACT-3' and antisense $5^{\prime}$-GGCATCGAAGGTGGAAGAGT-3' with the probe 5'-AGGACCAGGTTGTCTCCTGCGA-3' labeled with Cal fluoro red-610 and BHQ-2.

Reactions were performed using an iCycler iQ5 real time PCR machine (Bio-Rad). PCR conditions were optimized to generate $>95 \%$ PCR efficiency, and only those reactions between 95 and 105\% efficiency were included in subsequent analysis. Cycle threshold $(\mathrm{Ct})$ was obtained for each sample. A corrected $\mathrm{Ct}(\delta \mathrm{Ct})$ was calculated by subtracting the GAPDH Ct from the unknown sample $\mathrm{Ct}$ for each sample. Relative differences from the control sample were then calculated by using the following formula: fold change $=2$ (control $\delta \mathrm{Ct}$ minus sample $\delta \mathrm{Ct}$ ).

Hormonal assay. Blood from female mice was obtained by mandibular vein puncture in the morning and vaginal lavage was performed at the same time for cytological assessment. Blood was centrifuged at $4000 \times g$ for $15 \mathrm{~min}$ at $4^{\circ} \mathrm{C}$, and serum was collected and stored at $-80^{\circ} \mathrm{C}$ until needed. LH and FSH were measured using a Milliplex MAP immunoassay (Rat Pituitary panel, Millipore) in the Luminex200. Analysis was performed using the XPonent 3.0 software program with Logistic $5 \mathrm{D}$ Weighted analyses. Further analysis details are described by Singh et al. (2009). Estradiol was measured with an estradiol enzyme immunoassay kit (Cayman Chemical) according to the manufacturer's directions.

The mouse surge protocol was adapted from Christian et al. (2005) with modifications. Mice were ovariectomized (OVX) in the morning (day 0 ) and diluted $17-\beta$ estradiol (Cayman Chemical Company) filled alzet micro-osmotic pumps (model 1007D, DURECT) were inserted under the skin dorsally at the neck. $17-\beta$ estradiol was dissolved in ethanol at a concentration of $750 \mathrm{ng} / \mu \mathrm{l}$. This solution was further diluted with PBS to a final concentration of $7.5 \mathrm{ng} / \mu \mathrm{l}$ and injected into the mini-pump. Estradiol is released at $90 \mathrm{ng} / \mathrm{ml}$ per day by the pump, with a $0.5 \mu \mathrm{l} / \mathrm{h}$ rate. On day 2 , blood was taken $(\sim 50 \mu \mathrm{l})$ from each individual OVX mouse by mandibular vein puncture at 10:00 A.M., 4:00 P.M., and $1 \mathrm{~h}$ before lights off at 8:00 P.M. Intact control mice and their Jak2 $\mathrm{G}^{-\prime-}$ littermates were bled at 8:00 P.M. for 7 consecutive days, and vaginal lavage for estrous cycle assessment was performed at the same time.

Another group of mice treated as above were perfused at 8:00 P.M., and brains were preserved for colocalization of GnRH and c-Fos.

Histology. Ovaries were collected at metestrus or diestrus and fixed in $10 \%$ buffered formalin phosphate (Fisher Scientific) solution and stored at $4^{\circ} \mathrm{C}$. Paraffin-embedded ovaries were sectioned at $7 \mu \mathrm{m}$ thickness (Phenotype Core Facility, Johns Hopkins University School of Medicine). Ovarian sections were stained with hematoxylin and eosin, examined with a Zeiss microscope, and photographed with an AxioCamICc1 camera and exported to AxioVision Software.

Perfusion and immunostaining. Mice were anesthetized with ketamine and xylazine, and perfused transcardially with $0.9 \%$ saline followed by $4 \%$ para-
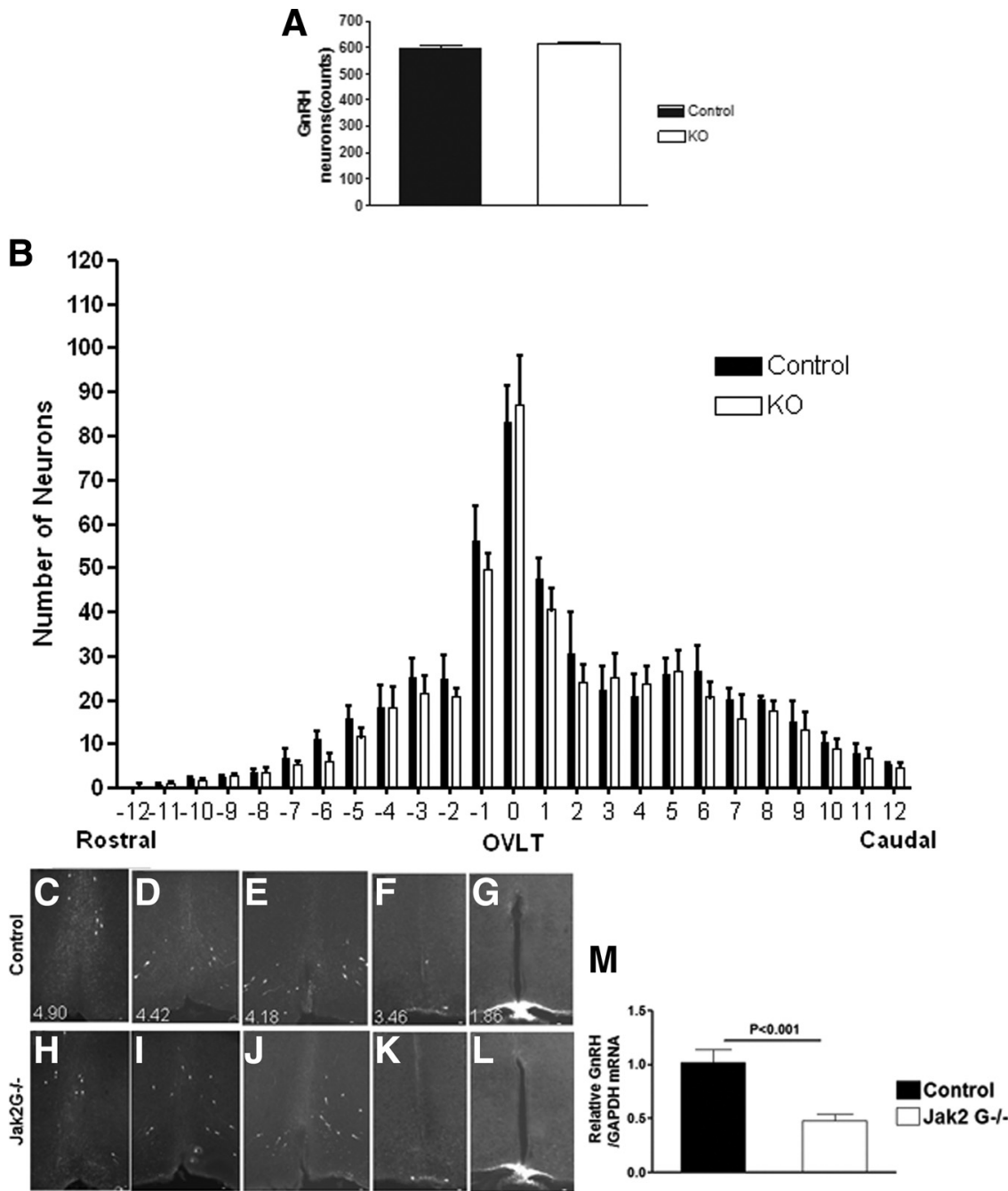

Figure 2. GnRH neuron cell number, distribution, and expression. $\boldsymbol{A}$, Brain of GnRH-GFP mice was sectioned at a thickness of 40

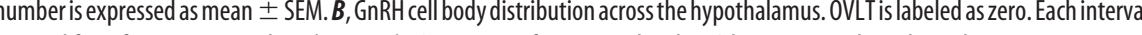
hour successive slices $(160 \mu \mathrm{m}) . C-L$, mages from control and a KO littermate at the indicated stereotaxic position Taqman Real time PCR assay for control $(n=8)$ and Jak2 $\mathrm{G}^{-1-}(n=10)$ mice expressed as fold change \pm SEM of normalized GnRH mRNA levels. Significance is indicated.

formaldehyde in $1 \times$ PBS. Brains were postfixed in $4 \%$ paraformaldehyde overnight and dehydrated in $30 \%$ sucrose for $24 \mathrm{~h}$ or until they sank to the bottom. Brains were then embedded in Optimal Cutting Temperature Compound at $-20^{\circ} \mathrm{C}$, and sections were cut coronally using a cryostat (HM550, MICROM) beginning rostrally at the olfactory bulb and ending caudally at the median eminence.

For the purpose of counting GnRH neurons, GnRH promoter-driven green fluorescent (GFP) (GnRH-GFP) mice obtained from Dan Spergel (University of Chicago, Chicago, IL) (Spergel et al., 1999) were used. Jak2 $\mathrm{G}^{-1-}$ mice were produced on the background of the GnRH-GFP mice. Forty micron sections were mounted onto slides with Vectashield (Vector Laboratories). All GnRH neurons were counted directly by GFP fluorescence by analyzing sequential section from the rostral olfactory tissue through the median eminence using a Zeiss microscope with X-Cite 120 Fluorescence Illumination System, photographed with an AxioCamMR camera, and exported to AxioVision Software. All images were exposed for $1 \mathrm{~s}$ with the same brightness and contrast parameters.

For the purpose of examining colocalization of GnRH and Jak2, brains of GnRH-GFP mice were coronally cut at $10 \mu \mathrm{m}$, mounted onto slides, and stored at $-20^{\circ} \mathrm{C}$ until needed. Slides were thawed at room temperature for $30 \mathrm{~min}$, and sections were washed three times with $1 \times$ PBS for 
A

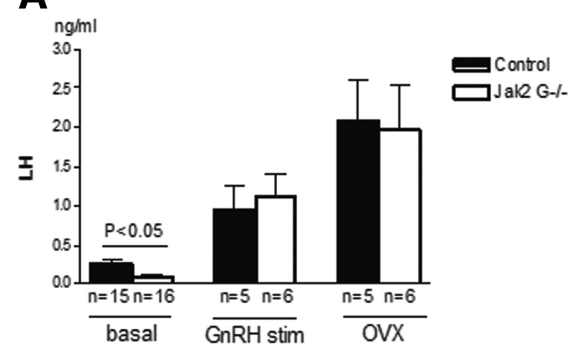

B

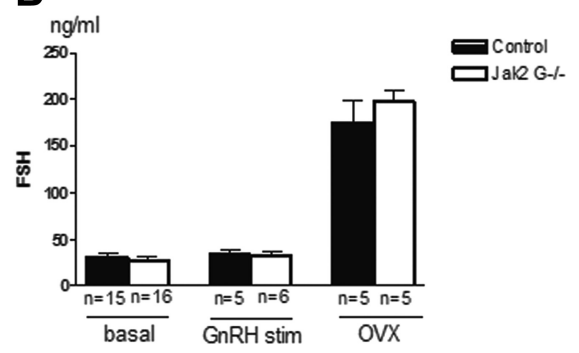

Figure 3. Hormonal assay. $\boldsymbol{A}$, Serum LH levels are graphed for basal, 10 min after GnRH stimulation or after OVX. $\boldsymbol{B}$, FSH levels for basal, 10 min after GnRH stimulation or after OVX. Values are mean \pm SEM, and significant differences are noted with brackets above bars.

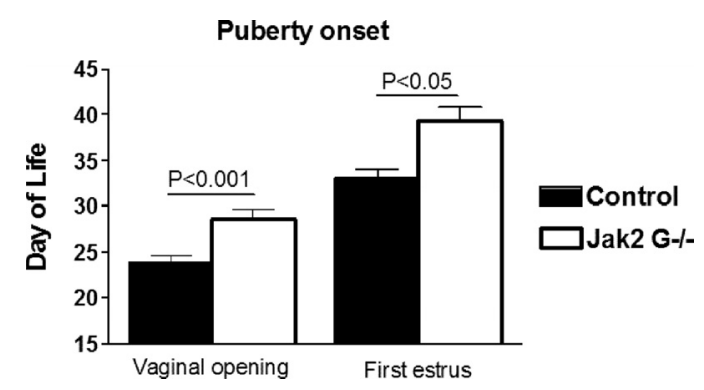

Figure 4. Female Jak2 $\mathrm{G}^{-1-}$ mice exhibit delayed puberty. Time of vaginal opening (V0) was examined daily from $21 \mathrm{~d}$ of life in both control $(n=20)$ and Jak2 $\mathrm{G}^{-1-}(n=14)$ littermates. Vaginal lavage was performed following V0, and the time of first estrus (defined as $100 \%$ cornified cells) was recorded ( $n=7$ each group). Values are mean $\pm \mathrm{SEM}$, and significance is indicated.

5 min each. Sections were then permeabilized with $0.25 \%$ Triton- 100 in $1 \times$ PBS for 6 min, washed two times with $1 \times$ PBS quickly, and blocked with $8 \%$ goat serum in $1 \times \mathrm{PBS}$ for $1 \mathrm{~h}$ at room temperature. Rabbit-anti Jak2 C-terminal polyclonal antibody (Santa Cruz Biotechnology) was diluted $1: 100$ in $0.02 \%$ Tween-20 of $1 \%$ BSA PBS. Sections were incubated with primary antibodies for $48 \mathrm{~h}$ and washed four to five times with PBS for 10 min each. Then sections were incubated with goat anti-rabbit IgG Alexa fluro-594 (Invitrogen) at 1:400 dilution in 0.02\% Tween-20 of $1 \%$ BSA PBS for $1.5 \mathrm{~h}$. Sections were then washed five times with $1 \times$ PBS for $10 \mathrm{~min}$ per wash. Sections were mounted with Vectashield and imaged as for GnRH-GFP neuronal counts.

For colocalizing c-Fos and GnRH, sections were cut at $30 \mu \mathrm{m}$ and stored in cryoprotectant antifreeze until use. Staining for c-Fos and GnRH used the same protocol and antibodies described by Hoffman et al. (2005). Stained sections were photographed with an AxioCamICc1 camera and exported to AxioVision Software.

Statistical analysis. All data were analyzed by unpaired Student's $t$ test using Prism software (GraphPad Software) and expressed as means \pm SEM. $p<0.05$ were defined as statistically significant.

\section{Results}

\section{Jak2-specific conditional knockout in GnRH neurons (Jak2 $\mathrm{G}^{-/-}$)}

Floxed Jak2 mice with LoxP sites flanking exon 2 (Fig. $1 \mathrm{~A}$ ) were mated with GnRH-Cre mice, which express the Cre recombinase gene in GnRH neurons. As expected, the KO allele (400 bp) was only found in the hypothalamus and not in other tissues of Jak2 $\mathrm{G}^{-1-}$ mice (Fig. 1 B). The Jak2 ${ }^{\mathrm{fl} / \mathrm{fl}}$ allele (320bp) was identified in all collected tissues from the same genomic DNA pool that was used for the Jak2 $\mathrm{G}^{-1-}$ PCR (Fig. $1 B$ ). To confirm cell-specific deletion of Jak2 in GnRH neurons, immunostaining for Jak2 was performed on $10 \mu \mathrm{m}$ brain sections. Figure $1 C$ shows GnRHexpressing neurons localized in the vertical limb diagonal

band in green, reflecting the expression of GFP under the direction of the murine GnRH promoter (Fig. 1C, top). Binding of the Jak2 antibody is visualized by red fluorescence (Alexa594) (Fig. 1C, middle). Overlaying the images shows Jak 2 colocalization in hypothalamic GnRH neurons of control GFP mice (Fig. 1C, bottom left) but no colocalization in $\mathrm{GnRH}$ neurons of Jak2 $\mathrm{G}^{-1-}$ GFP mice (Fig. 1C, bottom right). About 35\% of the GnRH cell bodies colocalized with Jak2 in control mice examined from the rostral olfactory bulb through the median eminence. We found no regional differences in colocalization within the hypothalamus.

To investigate whether the absence of Jak2 signaling in GnRH neurons affects $\mathrm{GnRH}$ neuronal development and migration, the number of GnRH neurons and their distribution were examined. There were a similar number of GnRH cell bodies [602.0 \pm 13.0 (control) vs $611.7 \pm 11.3\left(\mathrm{Jak} 2 \mathrm{G}^{-/-}\right.$)] (Fig. $2 \mathrm{~A}$ ) counted across the entire basal forebrain, and no significant difference in the number of GnRH cell bodies was observed in each successively counted region across the hypothalamus (Fig. 2B). A normal distribution of $\mathrm{GnRH}$ neurons was observed between Jak2 $\mathrm{G}^{-1-}$ and control groups (Fig. $2 \mathrm{C}-\mathrm{F}$, control; Fig. $2 \mathrm{H}-\mathrm{K}$, Jak2 $\mathrm{G}^{-1-}$; representative regions of the hypothalamus are shown). GnRH terminal distribution at the median eminence was examined to determine whether Jak2 signaling contributed to the axonal migration, a critical step in GnRH neuronal development, and was not found to differ between control and Jak2 $\mathrm{G}^{-1-}$ mice (Figs. $2 G, L$ respectively). Interestingly, results from quantitative realtime PCR showed that hypothalamic GnRH mRNA was reduced by $>50 \%$ of controls $(p<0.001)$ (Fig. $2 M)$.

\section{Jak2 $\mathrm{G}^{-/-}$mice have reduced serum $\mathrm{LH}$}

Basal serum LH levels from female Jak2 $\mathrm{G}^{-1-}$ mice were significantly reduced when compared with controls $[0.10 \mathrm{ng} / \mathrm{ml} \pm 0.02$, $n=16\left(\mathrm{Jak} 2 \mathrm{G}^{-1-}\right)$ vs $0.25 \mathrm{ng} / \mathrm{ml} \pm 0.06, n=15$ (control); $p<$ 0.05] (Fig. 3A). In contrast, female basal FSH levels were similar between Jak2 $\mathrm{G}^{-1-}$ mice and control mice $[26.34 \pm 5.07 \mathrm{ng} / \mathrm{ml}$, $n=16\left(\mathrm{Jak} 2 \mathrm{G}^{-1-}\right)$ vs $30.83 \mathrm{ng} / \mathrm{ml} \pm 5.17, n=15$ (control)] (Fig. $3 B$ ). To confirm that this difference in serum LH levels was not due to changes in pituitary responsiveness, a GnRH stimulation test was performed. The pituitaries from control and Jak2 $\mathrm{G}^{-1-}$ mice exhibited equal responses to $100 \mathrm{ng} / \mathrm{kg}$ body weight $\mathrm{GnRH}$ (Fig. $3 A, B$ ). No increase in FSH was observed at 10 min following GnRH stimulation in either Jak2 $\mathrm{G}^{-1-}$ or control mice.

Hypothalamic-pituitary gonadotropic activity is influenced by estrogen-negative feedback during most of the estrous cycle. When LH and FSH levels were measured following removal of negative feedback by OVX, there was no difference between Jak2 $\mathrm{G}^{-1-}$ and control littermates (Fig. $3 A, B$ ).

\section{Jak2 $\mathrm{G}^{-/-}$mice exhibit delayed puberty}

Vaginal opening has been shown to be an estrogen-dependent process and is used as an indicator of the onset of puberty ( $\mathrm{Sa}$ franski et al., 1993). The age of vaginal opening was significantly delayed in the Jak2 $\mathrm{G}^{-1-}$ mice compared with control littermates [29 $\pm 1.11 \mathrm{~d}$ of life (dol), $n=14\left(\mathrm{Jak} 2 \mathrm{G}^{-/-}\right.$) vs $24 \mathrm{dol} \pm 1.9, n=$ 20 (control), $p<0.001$ ] (Fig. 4). The day of first estrus implies progressive sexual maturation and is widely used as an indicator 
of progression through puberty (Safranski et al., 1993). Daily vaginal smears were obtained to identify the age of first estrus. Jak2 $\mathrm{G}^{-1-}$ mice exhibited a significant delay of first estrus compared with control littermates $[39.3 \pm 1.6 \mathrm{dol}, n=7$ (Jak2 $\mathrm{G}^{-/-}$) vs $33 \pm 1.1$ dol, $n=7$ (control), $p<0.01$ ] (Fig. 4). However, these data do not include the Jak $2 \mathrm{G}^{-1-}$ mice that had no first estrus when evaluated for up to 50 dol (two of nine examined).

Jak2 $\mathrm{G}^{-/-}$mice have abnormal estrous cycles and impaired ability to generate an LH surge

Vaginal cytology was analyzed from adult female mice for 15 consecutive days and demonstrated that Jak2 $\mathrm{G}^{-1-}$ mice $(n=$ 8 ) exhibited irregular estrous cycles when compared with their control littermates $(n=17$ ) (Fig. $5 A-C)$ ). During the $15 \mathrm{~d}$ of analysis, only $50 \%$ of Jak $2 \mathrm{G}^{-1-}$ mice had one complete cycle, compared with 95\% in the control group. Furthermore, only two of eight Jak2 $\mathrm{G}^{-/-}$mice $(25 \%)$ had two complete cycles in the $15 \mathrm{~d}$ period, whereas $82 \%$ of the control littermates exhibited two complete cycles (Fig. 5A). The duration spent in the proestrus phase in Jak2 $\mathrm{G}^{-/-}$mice was significantly shortened compared with control littermates (Fig. 5B). Acyclic mice mainly remained predominantly in persistent metestrus/ diestrus (Fig. 5C).

In female mice, the gonadotropic $\mathrm{LH}$ surge stimulates ovulation, which is an essential process in fertility and is induced by positive feedback of estradiol on the hypothalamus and pituitary. To explore whether positive feedback regulation is disrupted in Jak2 $\mathrm{G}^{-1-}$ mice, a surge induction paradigm was used (Christian et al., 2005) that produces LH surge generation within $1 \mathrm{~h}$ before lights off on day 2 of the paradigm. Chronic treatment with estradiol in OVX females resulted in levels of LH that were near the limit of detection in both Jak $2 \mathrm{G}^{-1-}$ and control females at 10:00 A.M. and were elevated but not significantly different at 4:00 P.M. (data not shown). Surge LH levels in control mice at 8:00 P.M. on day 2 in our study were nearly identical to the levels observed by Christian et al. (2005). However, LH levels were significantly blunted in Jak2 $\mathrm{G}^{-l-}$ mice (Fig. 5D). The estrogen levels after OVX plus estrogen replacement in all genotypes were found to be $29.5 \pm 7.9 \mathrm{pg} / \mathrm{ml}(n=7)$, which is similar to estrogen levels in proestrus (Nelson et al., 1982; Christian et al., 2005; Wu et al., 2010) and is nearly threefold higher than the basal morning circulating levels in intact female mice $[\sim 10 \mathrm{pg} / \mathrm{ml}$ for both wildtype (WT) and Jak2 $\mathrm{G}^{-/-}$mice; data not shown].

While Jak $2 \mathrm{G}^{-1-}$ mice frequently exhibit persistent diestrus, a number of $\mathrm{KO}$ females went through proestrus (Fig. $5 A-C$ ). To explore the magnitude of the $\mathrm{LH}$ surge in cycling females, evening blood samples were obtained in control and Jak2 $\mathrm{G}^{-1-}$ mice during the estrous cycle, and proestrus LH levels were found to be more than sixfold lower in Jak2 $\mathrm{G}^{-1-}$ mice compared with WT mice (data not shown).

\section{B}
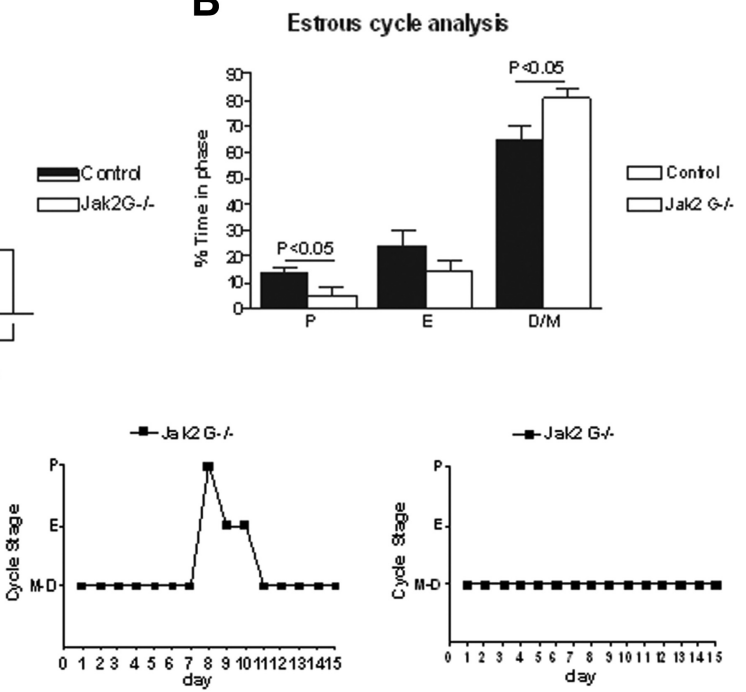

D

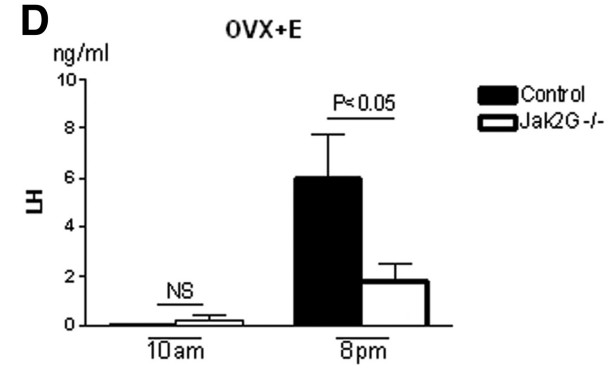

Jak2G-1-

Figure 5. Estrous cycle pattern in control and Jak2 $\mathrm{G}^{-1-}$ mice. Vaginal cytology was assessed for $15 \mathrm{~d}$ in control and Jak2 $\mathrm{G}^{-1-}$ mice. $\boldsymbol{A}$, Plotted are the percentage of females that exhibited one complete cycle during the $15 \mathrm{~d}$ (left two bars) or two (he $15 \mathrm{~d}$ (right two bars). Numbers of mice used to calculate the percentage are at the top of the bars. $\boldsymbol{B}_{\text {, }}$ $\mathrm{G}^{-1-}$ with irregular cycles, and Jak2 $\mathrm{G}^{-1-}$ without cycles. $\boldsymbol{D}, 0 \mathrm{VX}$ mice were implanted with an estradiol pump on day 0 and bled on day 2 (control $n=4$ vs Jak2 $\mathrm{G}^{-1-} n=7$ ). Values are mean \pm SEM, and significance is indicated.

\section{Jak2 $\mathrm{G}^{-1-}$ mice demonstrated attenuated GnRH neuronal activation during the surge}

To determine whether changes in GnRH neuronal activation correlated with the reduced LH levels during the surge, c-Fos immunostaining in GnRH neurons was assessed by dual labeling immunohistochemistry after mice underwent the surge induction paradigm. All sections with immunostained GnRH neurons were counted, and colocalization was documented in two regions, as has been described previously (d'Anglemont de Tassigny et al., 2010; Herbison et al., 2010). In both medial septum/ diagonal band of Broca (MS/DBB) and organum vasculosum of the lamina terminalis/rostral preoptic area (OVLT/rPOA) regions, we observed a significantly higher percentage of $\mathrm{GnRH}$ neurons with c-Fos in control mice than Jak2 $\mathrm{G}^{-I-}$ mice (104 and $115 \%$, respectively, more dual-labeled neurons for the MS/ $\mathrm{DBB}$ and VOLT/rPOA) (Fig. 6A-C).

\section{Jak2 $\mathrm{G}^{-1-}$ mice exhibit impaired fertility}

Fertility was also examined in control and Jak2 $\mathrm{G}^{-/-}$mice in a continuous mating protocol. Jak $2 \mathrm{G}^{-1-}$ female mice demonstrated an impaired ability to produce offspring, as shown in the mating paradigm in Figure 7A. The birth of each litter is represented by a black dot, and litter sizes are indicated by numbers above each line for every successful mating event. Jak2 $\mathrm{G}^{-/-}$mice exhibited decreased fertility compared with control littermates (Fig. 7A). None of the 8 Jak2 $\mathrm{G}^{-1-}$ females had four litters during 
A

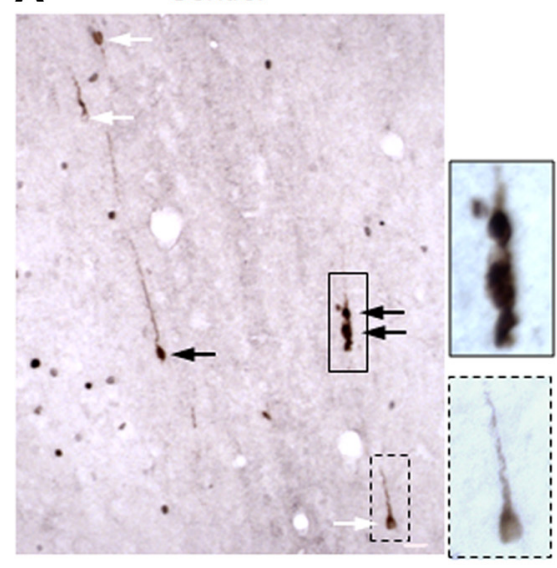

B

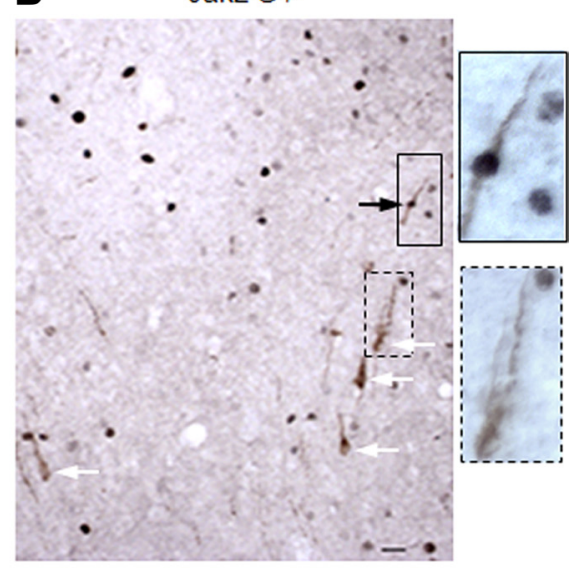

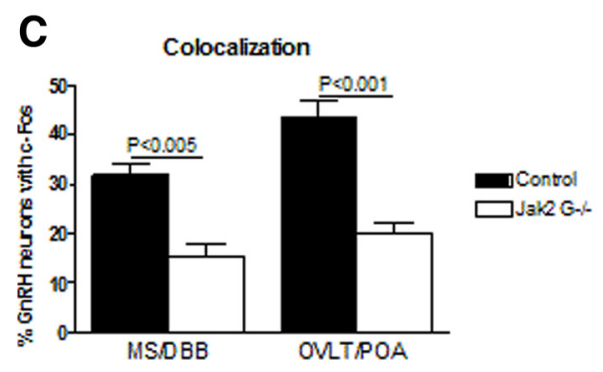

Figure 6. Colocalization of GnRH and c-Fos after surge generation. $\boldsymbol{A}, \boldsymbol{B}$, Images of dual labeling of $G n R H$ and c-Fos in control $(\boldsymbol{A})$ and Jak2 $\mathrm{G}^{-1-}$ mice $(\boldsymbol{B})$ at the level of the OVLT. Black arrows point to neurons with labeling of c-Fos (black/gray dot) and GnRH neuron (brown color). White arrows point to neurons labeled only for GnRH. A neuron with dual labeling is bordered by a solid line, with higher magnification to the right. A neuron with only $\mathrm{GnRH}$ staining is bordered by a dashed line, with higher magnification to the right. Scale bar, $20 \mu \mathrm{m}$. C, Percentage of $\mathrm{GnRH}$ neurons with c-Fos at two different regions ( $n=4$ per group). Values are mean \pm SEM, and significance is indicated.

the $90 \mathrm{~d}$ mating period where four of the six control mice had four litters in this period. Quantification of these data indicates that female Jak2 $\mathrm{G}^{-1-}$ mice bore their first litter significantly later after introduction to males than control female mice $[33.63 \pm$ $6.71 \mathrm{~d}, n=8$ (control) vs $22.00 \pm 0.47 \mathrm{~d}, n=14\left(\mathrm{Jak}_{2} \mathrm{G}^{-1-}\right.$ ); $p<0.05$ ] (Fig. $7 B$ ). During $90 \mathrm{~d}$ of mating, female Jak2 $\mathrm{G}^{-1-}$ mice had a significantly fewer number of litters per female [2.5 \pm $0.33, n=8\left(\mathrm{Jak} 2 \mathrm{G}^{-1-}\right)$ vs $3.67 \pm 0.21, n=6($ control $) ; p<0.05$ ] and a reduced number of pups per litter (5.6 $\pm 0.6, n=20$ (Jak2 $\mathrm{G}^{-/-}$) vs $12.0 \pm 1.76, n=27$ (control); $\left.p<0.01\right]$ compared with control females (Fig. 7C,D).

Since impaired neuroendocrine function is expected to result in fewer ovulations, we next counted corpora lutea from ovaries obtained from 4-month-old mice. A dramatic decrease in the number of corpora lutea from Jak2 $\mathrm{G}^{-1-}$ mice compared with controls $\left[7.25 \pm 1.3, n=4\left(\mathrm{Jak} 2 \mathrm{G}^{-1-}\right)\right.$ vs $17 \pm 2.3, n=4$ (control); $p<0.01$ ] (Fig. $8 A, B$ ) directly reflects a reduction in the number of follicles that have ovulated. The ovarian weights were also found to be significantly reduced in Jak2 $\mathrm{G}^{-1-}$ mice compared with control mice in diestrus $(7.68 \mathrm{mg} \pm 0.89, n=6$ [Jak2 $\mathrm{G}^{-/-}$) vs $11.79 \mathrm{mg} \pm 0.10, n=8$ (control); $p<0.01$ ] (Fig. $8 \mathrm{C}$ ) and is likely due to the reduced number of corpora lutea.

\section{Discussion}

The regulation of reproductive function by the brain is mediated by the pulsatile secretion of GnRH from the hypothalamus. Numerous signals are integrated by the brain and ultimately result in changes in GnRH neuronal activity, which may activate or inhibit reproductive function. The signaling pathways in GnRH neurons that mediate these cues, including regulation by cytokines such as LIF and CNTF, have been characterized to some extent using in vitro cell culture models of transformed GnRH neurons (Dozio et al., 2005; Magni et al., 2007). Here, we show that the Jak2 signaling molecule within the GnRH neuron plays an important role in the regulation of puberty and reproduction in vivo.

Few in vivo studies have explored the role of Jak2 in reproductive neuroendocrine function, although recent work has shown that specific disruption of STAT3 in the neurons of the CNS (STAT3 ${ }^{\mathrm{N}-/-}$ ) mimics leptin receptor-disrupted $(\mathrm{db} / \mathrm{db})$ and leptin-deficient (ob/ob) mice in the regulation of energy homeostasis and reproduction (Gao et al., 2004). However, the role of neuronal STAT3 signaling on reproduction is leptin receptor independent (Bates et al., 2003); therefore, STAT3 is mediating nonleptinergic signals in the brain to impact reproductive function. The present studies were undertaken to determine whether $\mathrm{GnRH}$ neurons are a locus in which disrupted Jak2/STAT3 signaling may contribute to the infertility observed in the STAT3 ${ }^{\mathrm{N}-1-}$ mouse. A CNS STAT5 KO mouse has also been produced (Lee et al., 2008), and the mice are fertile although specific parameters of reproductive function were not analyzed (M. Myers, personal communication). While the phenotypic analyses of the STAT KO mice provide important information about the role of STAT in the regulation of energy balance and reproduction, we sought to specifically explore the role of Jak2 in GnRH neuronal function.

We used Cre-LoxP technology to generate mice lacking Jak2 in GnRH neurons without interfering with peripheral Jak2 function (Jak2 $\mathrm{G}^{-1-}$ mice). The GnRH-Cre mouse (Wolfe et al., 2008) has been validated to target Cre expression to GnRH neurons in the hypothalamus and was crossed with a floxed Jak2 mouse, which has been shown to be viable and fertile and to effectively exhibit recombination in cells expressing Cre (Krempler et al., 2004; Wagner et al., 2004). We demonstrate that Cre recombinase expression in the GnRH neurons of the hypothalamus results in ablation of Jak2 expression (Fig. 1). Hypothalamus-specific deletion of Jak2 was demonstrated by PCR analysis of genomic DNA from peripheral tissues such as heart, liver, pituitary, ovary, and nonhypothalamic brain structures such as cerebellum and cortex (Fig. $1 \mathrm{~B})$; GnRH neuron-specific deletion was confirmed by immunohistochemical analysis of the brain (Fig. 1C).

Phenotypic analysis of the Jak2 $\mathrm{G}^{-1-}$ mice indicated that there was a significant delay in puberty in females (Fig. 4). Onset of puberty can be changed by genetic and external factors, and various markers can be used such as vaginal opening, first estrus, and cyclicity. Vaginal opening is steroid dependent and therefore indirectly assays the age of GnRH neuronal activation that underlies puberty. While the age of puberty varies widely in different mouse strains (Pinter et al., 2007), the examination of littermates in these analyses revealed a significant delay in puberty in female Jak2 $\mathrm{G}^{-1-}$ mice (Fig. 4). The delay in puberty is not the result of 
reduced numbers of $\mathrm{GnRH}$ cell bodies or terminals (Fig. 2A-L) as has been shown in another mouse model demonstrating delayed puberty (Herbison et al., 2008), suggesting that an intrinsic change in function of the GnRH neuron underlies the delay in puberty. A number of factors has been proposed to regulate the elaboration of puberty including, leptin (Ahima et al., 1997), kisspeptin (Kiss-1) (Seminara et al., 2003), and IGF-1 (Hiney et al., 1991; Divall et al., 2010). Although leptin and its receptor have been reported to influence puberty, this is most likely not at the level of the GnRH neuron as we (data not shown) and others (Quennell et al., 2009) have not detected the functional form of leptin receptor mRNA (long form). Moreover, the leptin receptor has been conditionally deleted in GnRH neurons and shown to have no effect on female puberty (Quennell et al., 2009). Kiss-1 has recently been implicated as playing an essential role in controlling puberty in mice (Seminara et al., 2003). The Kiss-1 receptor (Kiss-1R) has not been found to signal via Jak/STAT, so the delay in puberty observed in the Jak2 $\mathrm{G}^{-1-}$ mice suggests that overlapping signaling mechanisms exist. The contribution of Jak2-mediated signaling to pubertal development may explain the low-level activation of the reproductive axis observed in the Kiss- 1 and Kiss-1R KO mice (Chan et al., 2009), which exhibit less severe reproductive impairment when compared with mice lacking $\mathrm{GnRH}$ signaling (Mason et al., 1986; Wu et al., 2010). IGF-1 contributes to the elaboration of puberty in rats (Hiney et al., 1991, 1996) and mice (Divall et al., 2010), and, interestingly, has been shown to activate Jak/STAT signaling in 293T cells (Zong et al., 2000). While the Jak2 $\mathrm{G}^{-1-}$ mouse recapitulates the phenotype of the GnRH-IGF-1 receptor $\mathrm{KO}$ mouse with regard to a delay in puberty, the Jak2 $\mathrm{G}^{-/-}$exhibits significantly more severe reproductive defects. This supports a model in which Jak/ STAT is a common downstream pathway for multiple ligands.

Female Jak2 $\mathrm{G}^{-1-}$ mice exhibited impaired reproductive axis function and fertility. GnRH mRNA and LH levels were significantly decreased in female Jak $2 \mathrm{G}^{-1-}$ mice, suggesting that the reproductive dysfunction is due to attenuated $\mathrm{GnRH}$ function. The decrease in GnRH mRNA suggests that Jak/STAT signaling regulates GnRH gene expression. The decreased serum LH observed in the Jak2 $\mathrm{G}^{-1-}$ mice is likely due to a decrease in GnRH secretion and/or pulsatility. There were no recombination events detected in the pituitary (Fig. $1 B$ ), and GnRH stimulation
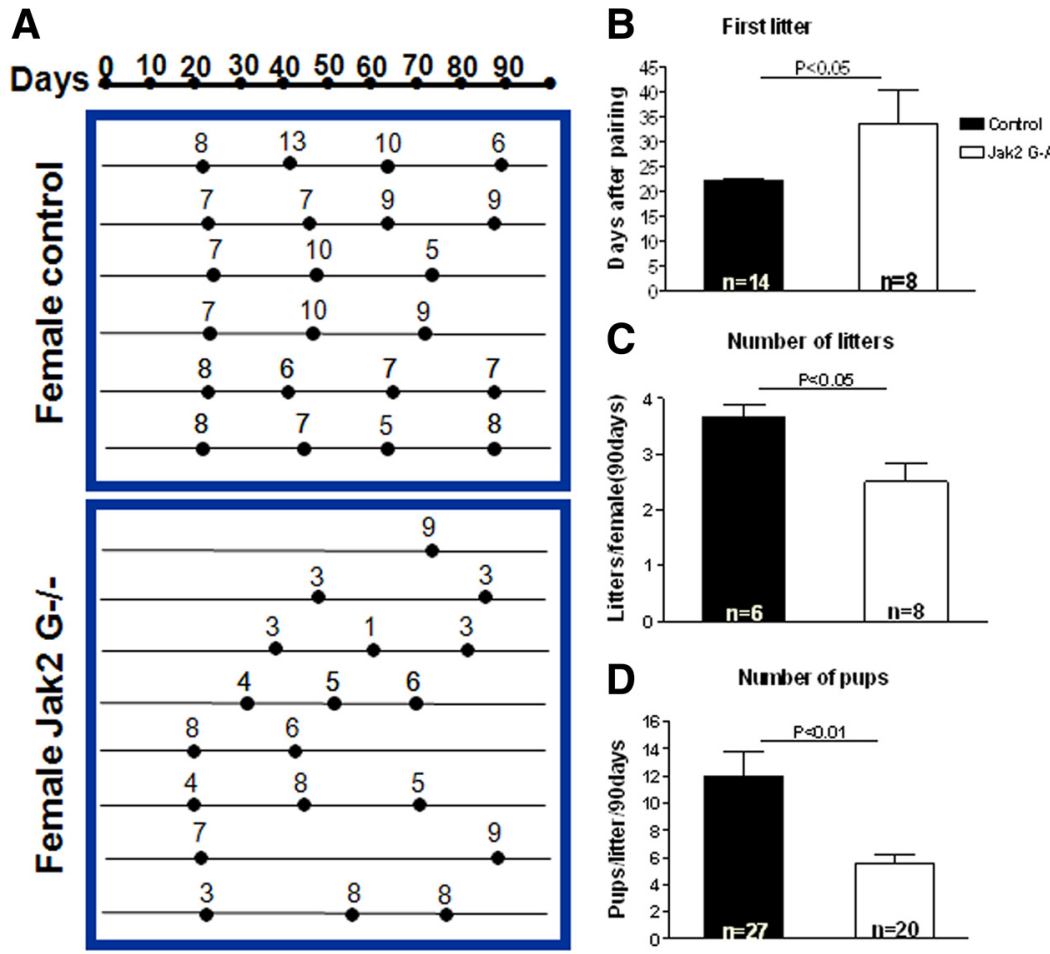

Figure 7. Fertility in control and Jak2 $\mathrm{G}^{-1-}$ female mice. $\boldsymbol{A}$, Female mice were mated with wild-type male mice for $90 \mathrm{~d}$. Each line represents an individual female mouse. The black dot represents the day that each litter was born after introduction to male. Number on the top of the line represents how many pups in each litter. Top, Female control mice. Bottom, Jak2 $\mathrm{G}^{-I-}$ female mice. Data from $\boldsymbol{A}$ are summarized in $\boldsymbol{B}-\boldsymbol{D}$. $\boldsymbol{B}$, After introduction with wild-type male, the day of first litter was recorded in both groups. C, Total numbers of litters per female was significantly reduced in Jak $2 \mathrm{G}^{-1-}$ mice compared with control mice during the $90 \mathrm{~d}$. $\boldsymbol{D}$, Number of pups per litter was significantly reduced in Jak2 $\mathrm{G}^{-1-}$ mice compared with controls. For $\boldsymbol{B}-\boldsymbol{D}$, values are mean \pm SEM, and significance and numbers of animals examined are indicated.
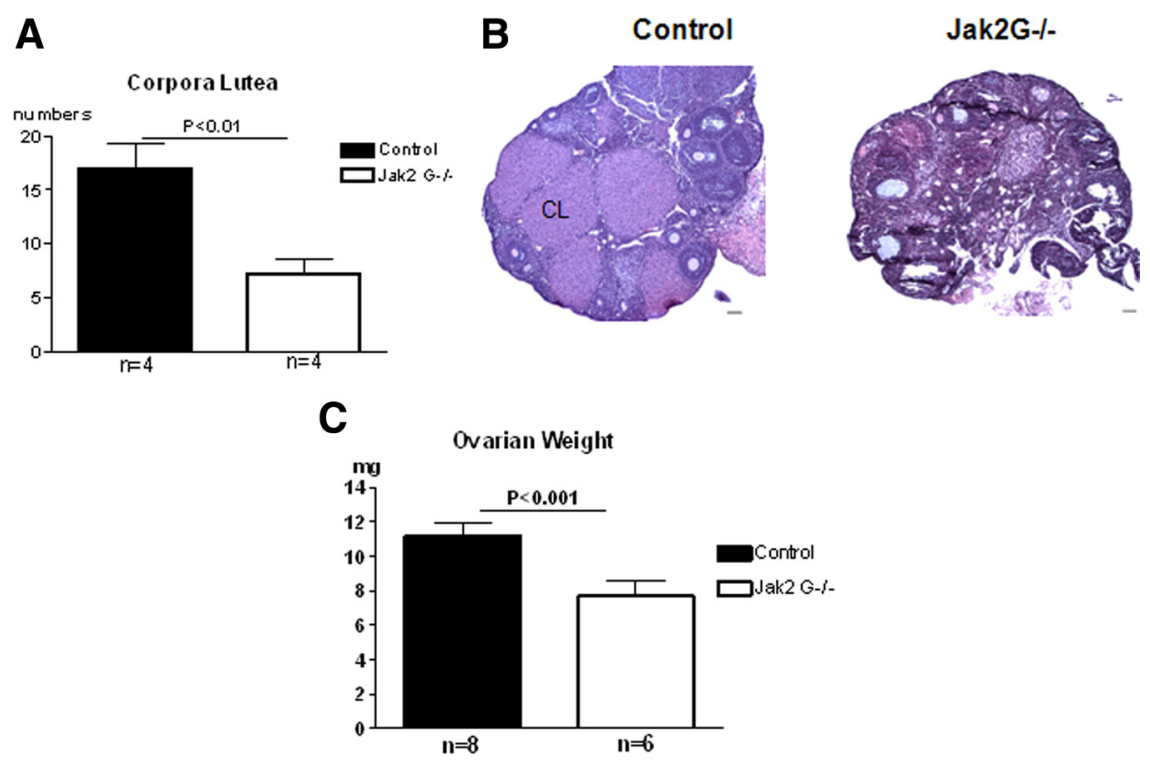

Figure 8. Ovarian morphology. $\boldsymbol{A}$, Ovary was sectioned at $7 \mu \mathrm{m}$ and corpora lutea (CL) were counted every 10 th section per ovary ( $n=4$ per group). $\boldsymbol{B}, 7 \mu \mathrm{m}$ ovary sections with hematoxylin-eosin staining. CL was labeled in the control ovary. $\boldsymbol{C}, 0$ varian weights $(\mathrm{mg})$ of control and Jak2 $\mathrm{G}^{-1-}$ mice $\left(n=8\right.$, control; $n=6$, Jak2 $\left.\mathrm{G}^{-1-}\right)$. Values are mean $\pm \mathrm{SEM}$, and significant differences are noted with brackets above bars.

testing revealed similar $\mathrm{LH}$ levels in the Jak $2 \mathrm{G}^{-1-}$ mice and control mice (Fig. 3A), implying intact pituitary function. Reduced activation of $\mathrm{GnRH}$ neurons, as assessed by c-Fos labeling (Hoffman et al., 2005), was observed in Jak2 $\mathrm{G}^{-1-}$ mice during the LH surge 
(Fig. 6), further demonstrating the dysfunction of the GnRH neuron.

Estrogen exerts both negative and positive feedback regulation of the hypothalamic-pituitary gonadotropic axis. Release from negative feedback results in stimulation of $\mathrm{GnRH}$ neuronal activity. Elevated GnRH secretion, coupled with reduced negative feedback at the level of the pituitary (Singh et al., 2009) produces an increase in LH secretion. We find no impairment in this process in the Jak2 $\mathrm{G}^{-1-}$ females as $\mathrm{LH}$ levels are equivalent to control mice (Fig. $3 A, B$ ). Thus, while there is reduced baseline secretion of GnRH in Jak2 $\mathrm{G}^{-1-}$ mice, this is not observed following release of negative feedback. It has been shown that kisspeptin likely mediates the stimulation of GnRH neuronal activity when estrogen-negative feedback is removed (Kauffman et al., 2007), and our results suggest that Jak/STAT-mediated signaling may not be contributing to this process or that kisspeptin stimulation of the GnRH neurons can compensate for disrupted Jak/STAT signaling in the complete absence of estradiol. Morning LH levels in estradiol-replaced OVX females were near the limit of detection of the assay in both Jak $2 \mathrm{G}^{-1-}$ and control mice (Fig. 5D), resulting from circulating estradiol levels that were designed to mimic proestrus levels.

Positive feedback by estradiol is essential for generating the preovulatory LH surge. We observed a significant attenuation in the LH surge in Jak2 $\mathrm{G}^{-1-}$ mice both in an induced surge paradigm (Fig. 5D) and in cycling females, suggesting that Jak2mediated signaling pathways contribute to the development of the LH surge. Further evidence for Jak/STAT-mediated activation of GnRH neurons during the surge is demonstrated by reduced levels of c-Fos observed in GnRH neurons in Jak $2 \mathrm{G}^{-1-}$ mice when compared with controls (Fig. 6). Kisspeptin is proposed to play an important role in estrogen-positive feedback effects on $\mathrm{GnRH}$ neuron function (Clarkson et al., 2008), although non-kisspeptin-mediated activation may also contribute to the generation of the LH surge (Dungan et al., 2007). Thus, multiple signaling pathways, including the Jak/STAT pathway, may contribute to the generation of the preovulatory surge.

Female Jak2 $\mathrm{G}^{-1-}$ mice also had a reduced number of litters and additionally exhibited a reduced number of pups per litter (Fig. 7C,D). LH levels influence follicle maturation, luteinization, and ovulation in female ovaries. Attenuated LH surge levels (Fig. $5 D)$ result in smaller litters in Jak2 $\mathrm{G}^{-1-}$ female mice and contribute to reduced ovarian weights and disrupted estrous cyclicity. The reduced ovarian weight is correlated with a significant reduction in numbers of corpora lutea (Fig. 8), which serves as a confirmation that there are reduced numbers of ovulations.

In conclusion, we report the development of a novel mouse model of Jak2 ablation in GnRH neurons. A role for Jak2 signaling in puberty and in the expression of the preovulatory gonadotropin surge has been demonstrated while Jak2 signaling does not appear to play a role in the regulation of estradiol-negative feedback. This work demonstrates the critical role of GnRH Jak2 in the integration of cellular signaling pathways that control mammalian reproduction.

\section{References}

Ahima RS, Dushay J, Flier SN, Prabakaran D, Flier JS (1997) Leptin accelerates the onset of puberty in normal female mice. J Clin Invest 99:391-395.

Argetsinger LS, Campbell GS, Yang X, Witthuhn BA, Silvennoinen O, Ihle JN, Carter-Su C (1993) Identification of JAK2 as a growth hormone receptor-associated tyrosine kinase. Cell 74:237-244.

Bartke A, Chandrashekar V, Turyn D, Steger RW, Debeljuk L, Winters TA, Mattison JA, Danilovich NA, Croson W, Wernsing DR, Kopchick JJ (1999) Effects of growth hormone overexpression and growth hormone resistance on neuroendocrine and reproductive functions in transgenic and knock-out mice. Proc Soc Exp Biol Med 222:113-123.

Bates SH, Stearns WH, Dundon TA, Schubert M, Tso AW, Wang Y, Banks AS, Lavery HJ, Haq AK, Maratos-Flier E, Neel BG, Schwartz MW, Myers MG $\mathrm{Jr}$ (2003) STAT3 signalling is required for leptin regulation of energy balance but not reproduction. Nature 421:856-859.

Bucholtz DC, Chiesa A, Pappano WN, Nagatani S, Tsukamura H, Maeda KI, Foster DL (2000) Regulation of pulsatile luteinizing hormone secretion by insulin in the diabetic male lamb. Biol Reprod 62:1248-1255.

Chan YM, Broder-Fingert S, Wong KM, Seminara SB (2009) Kisspeptin/ Gpr54-independent gonadotrophin-releasing hormone activity in Kiss1 and Gpr54 mutant mice. J Neuroendocrinol 21:1015-1023.

Christian CA, Mobley JL, Moenter SM (2005) Diurnal and estradioldependent changes in gonadotropin-releasing hormone neuron firing activity. Proc Natl Acad Sci U S A 102:15682-15687.

Clarkson J, d'Anglemont de Tassigny X, Moreno AS, Colledge WH, Herbison AE (2008) Kisspeptin-GPR54 signaling is essential for preovulatory gonadotropin-releasing hormone neuron activation and the luteinizing hormone surge. J Neurosci 28:8691-8697.

d'Anglemont de Tassigny X, Ackroyd KJ, Chatzidaki EE, Colledge WH (2010) Kisspeptin signaling is required for peripheral but not central stimulation of gonadotropin-releasing hormone neurons by NMDA. J Neurosci 30:8581-8590.

Danilovich N, Wernsing D, Coschigano KT, Kopchick JJ, Bartke A (1999) Deficits in female reproductive function in GH-R-KO mice; role of IGF-I. Endocrinology 140:2637-2640.

Divall SA, Williams TR, Carver SE, Koch L, Brüning JC, Kahn CR, Wondisford F, Radovick S, Wolfe A (2010) Divergent roles of growth factors in the GnRH regulation of puberty in mice. J Clin Invest 120:2900-2909.

Dozio E, Watanobe H, Ruscica M, Maggi R, Motta M, Magni P (2005) Expression of functional ciliary neurotrophic factor receptors in immortalized gonadotrophin-releasing hormone-secreting neurones. J Neuroendocrinol 17:286-291.

Dungan HM, Gottsch ML, Zeng H, Gragerov A, Bergmann JE, Vassilatis DK, Clifton DK, Steiner RA (2007) The role of kisspeptin-GPR54 signaling in the tonic regulation and surge release of gonadotropin-releasing hormone/luteinizing hormone. J Neurosci 27:12088-12095.

Franklin KBJ, Paxinos G (1997) The mouse brain in stereotaxic coordinates. San Diego: Academic.

Gao Q, Wolfgang MJ, Neschen S, Morino K, Horvath TL, Shulman GI, Fu XY (2004) Disruption of neural signal transducer and activator of transcription 3 causes obesity, diabetes, infertility, and thermal dysregulation. Proc Natl Acad Sci U S A 101:4661-4666.

Hamilton DL, Abremski K (1984) Site-specific recombination by the bacteriophage P1 lox-Cre system. Cre-mediated synapsis of two lox sites. J Mol Biol 178:481-486.

Herbison AE, Porteous R, Pape JR, Mora JM, Hurst PR (2008) Gonadotropin-releasing hormone neuron requirements for puberty, ovulation, and fertility. Endocrinology 149:597-604.

Herbison AE, de Tassigny X, Doran J, Colledge WH (2010) Distribution and postnatal development of Gpr54 gene expression in mouse brain and gonadotropin-releasing hormone neurons. Endocrinology 151:312-321.

Hiney JK, Ojeda SR, Dees WL (1991) Insulin-like growth factor I: a possible metabolic signal involved in the regulation of female puberty. Neuroendocrinology 54:420-423.

Hiney JK, Srivastava V, Nyberg CL, Ojeda SR, Dees WL (1996) Insulin-like growth factor I of peripheral origin acts centrally to accelerate the initiation of female puberty. Endocrinology 137:3717-3728.

Hoffman GE, Le WW, Schulterbrandt T, Legan SJ (2005) Estrogen and progesterone do not activate Fos in AVPV or LHRH neurons in male rats. Brain Res 1054:116-124.

Ihle JN (1995) Cytokine receptor signalling. Nature 377:591-594.

Kauffman AS, Gottsch ML, Roa J, Byquist AC, Crown A, Clifton DK, Hoffman GE, Steiner RA, Tena-Sempere M (2007) Sexual differentiation of Kiss1 gene expression in the brain of the rat. Endocrinology 148:1774-1783.

Kisseleva T, Bhattacharya S, Braunstein J, Schindler CW (2002) Signaling through the JAK/STAT pathway, recent advances and future challenges. Gene 285:1-24.

Krempler A, Qi Y, Triplett AA, Zhu J, Rui H, Wagner KU (2004) Generation of a conditional knockout allele for the Janus kinase 2 (Jak2) gene in mice. Genesis 40:52-57. 
Lee JY, Muenzberg H, Gavrilova O, Reed JA, Berryman D, Villanueva EC, Louis GW, Leinninger GM, Bertuzzi S, Seeley RJ, Robinson GW, Myers MG, Hennighausen L (2008) Loss of cytokine-STAT5 signaling in the CNS and pituitary gland alters energy balance and leads to obesity. PLoS One 3:e1639.

Magni P, Dozio E, Ruscica M, Watanobe H, Cariboni A, Zaninetti R, Motta M, Maggi R (2007) Leukemia inhibitory factor induces the chemomigration of immortalized gonadotropin-releasing hormone neurons through the independent activation of the Janus kinase/signal transducer and activator of transcription 3, mitogen-activated protein kinase/extracellularly regulated kinase $1 / 2$, and phosphatidylinositol 3-kinase/Akt signaling pathways. Mol Endocrinol 21:1163-1174.

Mason AJ, Hayflick JS, Zoeller RT, Young WS 3rd, Phillips HS, Nikolics K, Seeburg PH (1986) A deletion truncating the gonadotropin-releasing hormone gene is responsible for hypogonadism in the hpg mouse. Science 234:1366-1371.

Nagatani S, Bucholtz DC, Murahashi K, Estacio MA, Tsukamura H, Foster DL, Maeda KI (1996) Reduction of glucose availability suppresses pulsatile luteinizing hormone release in female and male rats. Endocrinology 137:1166-1170.

Nelson JF, Felicio LS, Randall PK, Sims C, Finch CE (1982) A longitudinal study of estrous cyclicity in aging C57BL/6J mice: I. Cycle frequency, length and vaginal cytology. Biol Reprod 27:327-339.

Parganas E, Wang D, Stravopodis D, Topham DJ, Marine JC, Teglund S, Vanin EF, Bodner S, Colamonici OR, van Deursen JM, Grosveld G, Ihle JN (1998) Jak2 is essential for signaling through a variety of cytokine receptors. Cell 93:385-395.

Pellegrini S, Dusanter-Fourt I (1997) The structure, regulation and function of the Janus kinases (JAKs) and the signal transducers and activators of transcription (STATs). Eur J Biochem 248:615-633.

Pinter O, Beda Z, Csaba Z, Gerendai I (2007) Differences in the onset of puberty in selected inbred mouse strains. Endocr Abstr 14:P617.

Pitteloud N, Quinton R, Pearce S, Raivio T, Acierno J, Dwyer A, Plummer L, Hughes V, Seminara S, Cheng YZ, Li WP, Maccoll G, Eliseenkova AV, Olsen SK, Ibrahimi OA, Hayes FJ, Boepple P, Hall JE, Bouloux P, Mohammadi M, et al. (2007) Digenic mutations account for variable phenotypes in idiopathic hypogonadotropic hypogonadism. J Clin Invest 117:457-463.

Popa SM, Clifton DK, Steiner RA (2008) The role of kisspeptins and GPR54 in the neuroendocrine regulation of reproduction. Annu Rev Physiol 70:213-238.

Porkka-Heiskanen T, Khoshaba N, Scarbrough K, Urban JH, Vitaterna MH, Levine JE, Turek FW, Horton TH (1997) Rapid photoperiod-induced increase in detectable GnRH mRNA-containing cells in Siberian hamster. Am J Physiol 273:R2032-R2039.

Quennell JH, Mulligan AC, Tups A, Liu X, Phipps SJ, Kemp CJ, Herbison AE, Grattan DR, Anderson GM (2009) Leptin indirectly regulates gonado- tropin-releasing hormone neuronal function. Endocrinology 150:28052812.

Safranski TJ, Lamberson WR, Keisler DH (1993) Correlations among three measures of puberty in mice and relationships with estradiol concentration and ovulation. Biol Reprod 48:669-673.

Seminara SB, Messager S, Chatzidaki EE, Thresher RR, Acierno JS Jr, Shagoury JK, Bo-Abbas Y, Kuohung W, Schwinof KM, Hendrick AG, Zahn D, Dixon J, Kaiser UB, Slaugenhaupt SA, Gusella JF, O'Rahilly S, Carlton MB, Crowley WF Jr, Aparicio SA, Colledge WH (2003) The GPR54 gene as a regulator of puberty. $\mathrm{N}$ Engl J Med 349:1614-1627.

Shillingford JM, Miyoshi K, Robinson GW, Grimm SL, Rosen JM, Neubauer H, Pfeffer K, Hennighausen L (2002) Jak2 is an essential tyrosine kinase involved in pregnancy-mediated development of mammary secretory epithelium. Mol Endocrinol 16:563-570.

Singh SP, Wolfe A, Ng Y, DiVall SA, Buggs C, Levine JE, Wondisford FE, Radovick S (2009) Impaired estrogen feedback and infertility in female mice with pituitary-specific deletion of estrogen receptor alpha (ESR1). Biol Reprod 81:488-496.

Smith MS, Grove KL (2002) Integration of the regulation of reproductive function and energy balance: lactation as a model. Front Neuroendocrinol 23:225-256.

Spergel DJ, Krüth U, Hanley DF, Sprengel R, Seeburg PH (1999) GABAand glutamate-activated channels in green fluorescent protein-tagged gonadotropin-releasing hormone neurons in transgenic mice. J Neurosci 19:2037-2050.

Stanley SA, Todd JF, Small CJ, Kim MS, Heath MM, Anand P, Ghatei MA, Bloom SR (2000) The effects of ciliary neurotrophic factor on the hypothalamo-pituitary gonadal axis in vitro in female rats. J Neuroendocrinol 12:1009-1013.

Wagner KU, Krempler A, Triplett AA, Qi Y, George NM, Zhu J, Rui H (2004) Impaired alveologenesis and maintenance of secretory mammary epithelial cells in Jak2 conditional knockout mice. Mol Cell Biol 24:5510-5520.

Watanobe H, Yoneda M (2001) A significant participation of leukemia inhibitory factor in regulating the reproductive function in rats: a novel action of the pleiotropic cytokine. Biochem Biophys Res Commun 282:643-646.

Wolfe A, Divall S, Singh SP, Nikrodhanond AA, Baria AT, Le WW, Hoffman GE, Radovick S (2008) Temporal and spatial regulation of CRE recombinase expression in gonadotrophin-releasing hormone neurones in the mouse. J Neuroendocrinol 20:909-916.

Wu S, Wilson MD, Busby ER, Isaac ER, Sherwood NM (2010) Disruption of the single copy gonadotropin-releasing hormone receptor in mice by gene trap: severe reduction of reproductive organs and functions in developing and adult mice. Endocrinology 151:1142-1152.

Zong CS, Chan J, Levy DE, Horvath C, Sadowski HB, Wang LH (2000) Mechanism of STAT3 activation by insulin-like growth factor I receptor. J Biol Chem 275:15099-15105. 